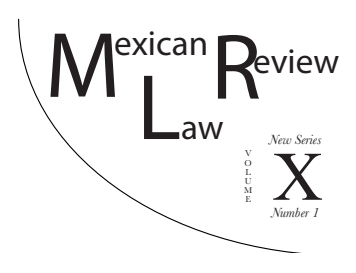

\title{
THE RECOGNITION OF FOREIGN LAW: FOREIGN MARITIME LIENS UNDER MEXICAN LAW
}

\author{
Abraham Alejandro Servín CAamaÑo*
}

\begin{abstract}
Maritime liens, without a doubt, are a unique and hugely important feature of maritime law. Broadly speaking, they represent a claim on or special right to a vessel. However, there is no uniformity when it comes to studying this unique feature. It is from the Anglo-Saxon jurisdictions that we get the majority of our information about its nature and associated problems. In this article, the law on maritime liens is examined through a comparative study of several Anglo-Saxon jurisdictions and Mexican law. Also under investigation are the problems that arise when a national court is faced with a maritime lien created under foreign law, and when that maritime lien differs from those liens established under the law that governs the domestic court.
\end{abstract}

Key Words: Maritime liens, Foreign Law, Substantive Law, Procedural Law, Arrest of ships.

RESUMEN: Sin lugar a duda los privilegios marítimos representan una figura única y de suma importancia del derecho marítimo. A grandes rasgos se puede decir que un privilegio marítimo es un crédito o privilegio sobre un buque, sin embargo, es en sus particularidades que no hay uniformidad a la hora de estudiar esta figura tan única. De tal modo que son las jurisdicciones anglosajonas aquellas que nos dan mayor detalle sobre la naturaleza y problemas que surgen de su estudio. En este trabajo se estudia el derecho de los privilegios marítimos a través de un estudio comparativo de varias jurisdicciones anglosajonas y el derecho Mexicano. Luego, se estudian los problemas que surgen cuando un juez nacional se enfrenta con un privilegio marítimo nacido bajo el derecho extranjero, y aun ms importante cuando ese privilegio marítimo difiere de aquellos establecidos en su legislación.

* LL.M. in Maritime Law, University of Southampton, United Kingdom; B.Sc. in International Relations, UNAM, Mexico. 
Esta revista forma parte del acervo de la Biblioteca Jurídica Virtual del Instituto de Investigaciones Jurídicas de la UNAM www.juridicas.unam.mx

Palabras clave: Privilegios maritimos, derecho extranjero, derecho sustantivo, derecho procedimental, embargo precautorio de buques.

TABLE OF CONTENTS:

I. INTRODUCTION.

II. What is A Maritime LiEn?.

1. Maritime Liens Under English Common Law.

2. Maritime Liens Under United States Law

3. Maritime Liens Under Mexican Law.

III. Recognition of Foreign Maritime Liens.

1. Other Furisdiction and the Recognition of Foreign Maritime Liens.......

2. An Approach to the Recognition of Foreign Maritime Liens Under Mexican Law.....

\section{INTRODUCTION}

Maritime law is a unique branch of the law. Among its areas of specialization is admiralty law. Because of its nature, admiralty law requires deep knowledge of other areas of the law such as insurance, environmental, international and contract laws.

Maritime transactions are based on good faith. The dynamism and nature of the maritime business sometimes require creditors to wait for payment. Vessels must navigate in order to earn money and pay dues, therefore, the creation of maritime credits or the right to a maritime claim has been of paramount importance to the development of international trade. For instance, a company that repairs a vessel needs security that its services will be paid. Without collateral, the company cannot allow the ship to sail away. A maritime lien can be said to provide greater security for a claimant than a regular maritime claim. The enforcement of a maritime lien through the arrest of the ship gives certainty to the claimant that negotiations for the provision of security by the P\&I Club or the bank will be held.

Despite the fact that the expression maritime lien is recognized in the national law of all countries, and that these nations are aware of the importance of this feature of maritime law, there is no global agreement on the precise character of maritime liens.

In fact, the law of maritime liens has developed differently across the globe, and substantial disparities remain in the way it is administered. Therefore, it is natural that conflicts of laws should arise in regard to claims of this nature. 
Specifically, when the discussion is about the recognition of foreign maritime liens, courts around the globe have used different approaches depending on their own conflict of laws rules, public policy and expertise in certain juridical areas. For instance, the approach used by common law countries is substantially different from that used by civil law countries.

This article analyzes the law on "maritime liens" and the problems that arise when a domestic court is faced with a maritime lien recognized under foreign law. The first part of this article analyzes and attempts to define the concept of maritime liens. This section also makes a comparative study of English, American and Mexican maritime laws. Part two offers an analysis of the position regarding the recognition of foreign maritime liens. In this chapter a study of the leading cases, mainly English, American, Canadian and Australian is done in order to predict what the Mexican court could do faced with a similar situation.

\section{What IS A MARITIMe LIEN?}

As stated by Sheen J. a maritime lien is more easily recognized than defined. ${ }^{1}$ For this reason it is necessary to analyze the features of maritime liens across different jurisdictions. In this article English common law, American law and Mexican law will be studied.

\section{Maritime Liens Under English Common Law}

The concept was first defined by Sir John Jervis in the Bold Buccleugh. ${ }^{2}$

A maritime lien, he said, is used in Maritime Law not in the strict legal sense in which we understand it in Courts of Common Law. ${ }^{3}$ A maritime lien is defined as a claim or privilege upon a thing to be carried into effect by legal process. ${ }^{4}$ This claim or privilege travels with the thing, into whosesoever possession it may come. ${ }^{5}$ It is inchoate from the moment the claim or privilege attaches, and, when carried into effect by legal process by a proceeding in rem, ${ }^{6}$ relates back to the period when it first attached. ${ }^{7}$

The maritime lien is the foundation of the admiralty proceeding in rem. An action in rem is restricted to the process of enforcing a maritime lien directly

\footnotetext{
1 The Father Thames 1979)2 Lloyd's Rep 364, 368.

2 The "Bold Buccleugh" [1851] 7 Moo PC 267.

Id. at 284.

4 Id.

Id. at 284, 285.

${ }^{6} I d$. at 284.

7 Id. at 285.
} 
against the ship as the defendant, in accordance with the provisions of the Senior Courts Act of 1981. This is called the personification theory, which through time, evolved into the procedural theory. Historically, if the owner of the ship appears or acknowledges service of the proceedings, the action also becomes an action in personam. ${ }^{8}$ This may be seen as a device to bring the shipowner into court and extend his liability, previously limited to the value of the ship. ${ }^{9}$

The Ripon City, ${ }^{10}$ established that a maritime lien may exist and be enforced against the property of persons not personally liable for the claim, and who are not the persons who, or whose servants, have required the service or done the damage. ${ }^{11}$ Furthermore, the person who has acquired the right cannot be deprived of it by alienation of the thing by the owner. ${ }^{12}$ In other words a maritime lien travels with the vessel into whosesoever hands it may pass.

Furthermore, Mellish LJ. noted in The Two Ellens ${ }^{13}$ that:

A maritime lien must be something which adheres to the ship from the time that the fact happened which gave the maritime lien, and then continues binding the ship until it is discharged, either by being satisfied from the assets of the owner, or in any other way by which, by law, it may be discharged. It commences, and there it continues binding on the ship until it comes to an end. ${ }^{14}$

A maritime lien can arise in a variety of contexts. In the Tolten, ${ }^{15}$ Scott L.J. states that the lien needs to be admitted or established by evidence. ${ }^{16}$ While a maritime lien for collision requires personal liability and may be tortuous in nature, a maritime lien for seafarer wages only requires that service was rendered to the ship ${ }^{17}$ arising independently of the shipowner's personal liability.

Additionally, in the Tolten it was stated that:

\footnotetext{
8 Further discussion on the real nature of maritime liens can be seen in the controversial decision in the Republic of India v India Steamship Co Ltd (no 2) [1994] 3 WLR 818 (HL). For a critique of this decision see Comandate Marine Corporation v Pan Australia Shipping Pty Ltd (the "comandate") 1 Lloyd's Rep. 119; also, Aleka Mandaraka-Shepard, Modern Maritime Law Volume 1, Jurisdiction ANd Risk 3-3.7(informa Law 2013).

9 Case note, Personification of Vessels, 77 Harv. L. Rev. 1123 (1963-1964).

10 The Ripon City [1897] P. 226.

11 Id. at 242.

12 Id.

13 The Two Ellens (1872) LR 4 PG 161.

14 Id. at 169 .

15 The tolten [1946] P. 135.

16 Id. at 146.

17 Common law provides many precedents about maritime liens, but an in deep study may require the separate study all types of maritime liens, from salvage to master's disbursements.
} 
The lien consists in the substantive right of putting into operation the Admiralty Court's executive function of arresting and selling the ship, so as to give clear title to the purchaser, and thereby, enforcing distribution of the proceeds amongst the lien creditors in accordance with their several priorities [... ${ }^{18}$

Finally, under English law, a very restricted list of claims may give rise to a maritime lien
I. Salvage.
II. Collision damage.

III. Seaman's wages.

IV. Bottomry (although bottomry is now obsolete).

V. Master's wages.

VI. Master's disbursements. ${ }^{19}$

\section{Maritime Liens Under United States Law}

United States Maritime liens share some features with common law maritime liens. In fact, the The Bold Buccleugh ${ }^{20}$ is considered to be a very important case both in England and the United States. In The Fohn G Stevens ${ }^{21}$ the Supreme Court describes a maritime lien for collision in a similar fashion to a maritime lien under English law:

The collision, as soon as it takes place, creates, as security for the damages, a maritime lien or privilege, jus in re, a proprietary interest in the offending ship, and which, when enforced by admiralty process in rem, relates back to the time of the collision. The offending ship is considered as herself the wrongdoer, and as herself bound to make compensation for the wrong done $[\ldots] .{ }^{22}$ (Emphasis added).

Therefore, in this section some unique features will be highlighted in order to understand maritime liens under other jurisdictions.

In The Brig Nestor, ${ }^{23}$ Story J. defined the character of a maritime lien according to US law and analyzed the nature of a maritime lien as a mixture of

\footnotetext{
18 The Tolten [1946] P. 135. at 145, 146.

19 Bankers Trust International Limited v Todd Shipyards Corporation (The Halcyon Isle)[1980] 2 Lloyd's Rep. 325 AT 332,333.

20 The "Bold Buccleugh" [1851] 7 Moo PC 267.

21 The "John G. Stevens" 170 U.S. 113 (1898).

22 Id. at 122, 123.

23 The Brig Nestor (1831)18 Fed Cas 9.
} 
Esta revista forma parte del acervo de la Biblioteca Jurídica Virtual del Instituto de Investigaciones Jurídicas de la UNAM www.juridicas.unam.mx

a tacit hypothecation, being a lien that is created by operation of law creating security without title or possession, and a privilege. ${ }^{24}$

Story J. also established that a maritime lien is enforced by an action in rem, which can only be executed by the US Admiralty Court. ${ }^{25}$ A lien arises from the vessel's wrong and creates an interest in the vessel that will be enforced by an action in rem which is allowed by the Federal Rules of Civil Procedure, Supplemental Rules for Certain Admiralty and Maritime Claims, Rule C.

The American action in rem is against the property that relates to the claim. This is possible due to a legal fiction called "personification of the vessel." 26 Moreover, the ship is invested with legal personality and is liable for its actions. For instance, in United States v. the Brig Malek Adhe ${ }^{27}$ Story J noted that the vessel will be liable for its torts and misconducts regardless of the innocence of the shipowner, stating that:

$[\ldots]$ the act makes no exception whatsoever, whether the aggression be with or without the co-operation of the owners. The vessel which commits the aggression is treated as the offender, as the guilty instrument or thing to which the forfeiture attaches, without any reference whatsoever to the character or conduct of the owner. The vessel or boat (says the act of Congress) from which such piratical aggression, shall have been first attempted or made shall be condemned $[\ldots]{ }^{28}$

Also, unlike an English maritime lien, a US maritime lien would not be barred by a previous action in personam against the owner of the offending vessel as in S.E.L. Maduro (Florida), INC v M/V Antonio De Gastaneta. ${ }^{29}$

Under American law then, there are a large number of claims that may give rise to a maritime lien, either because of "statutory law" or because of "case law". Robert Force provides a list of the claims that can give rise to a maritime lien:

\section{Seamen's wages.}

II. Salvage.

III. Torts that arise under the general maritime law.

IV. General average.

V. Preferred ship mortgages

\footnotetext{
24 Id. at $82-85$.

25 Id. at 78.

26 For further discussion on this see Alex T. Howard JR, Personification of the Vessel: Fact or Fiction?, 21 J. Mar. L. \& Com. 319-329 (1990).

27 United States v. Cargo of the Brig Malek Adhel, 43 U.S. 210 (1844).

$28 I d$. at 229.

29 S.E.L. Maduro (Florida), ING v M/V Antonio De Gastaneta 833 f.2d 1477, 1988 AMC 1217 (11th Cir. 1985).
} 
VI. Supplies.

VII. Repairs.

VIII. Necessaries furnished to vessel.

IX. Towage.

X. Wharfage.

XI. Pilotage.

XII. Stevedoring.

XIII. Damage or loss to cargo while aboard a vessel.

XIV. Claims by carriers for unpaid freight. ${ }^{30}$

\section{Maritime Liens Under Mexican Law}

Maritime liens are codified in articles 91 to 100 of the Navigation and Maritime Commerce Law (L.N.C.M in Spanish). ${ }^{31}$ Maritime liens or maritime privileges as they are called under Mexican law are defined in the first paragraph of Article 91: "Maritime liens give the preferential creditor the right to be privileged over other creditors regarding payment, in accordance with the provisions of this Act [...]." ${ }^{\prime 2}$

According to the L.N.C.M a maritime lien is a cause of preference attached to a real or personal right ${ }^{33}$ for the satisfaction of the claimant's right. Further explanation about the nature of a maritime lien is provided in Article 93:

Maritime liens on a vessel will be extinguished after a period of one year from the time the maritime lien arises, unless an action has been issued to seize the ship or to make the ship subject to preventive embargo.

The extinction of the maritime lien does not involve the extinction of the credit or compensation; they will become extinct in the form and terms indicated in the applicable legislation. ${ }^{34}$

30 Robert Force, Admiralty and Maritime Law 176 (Federal Juridical Center, 2d ed.2013).

31 Ley de Navegación y Comercio Marítimos[ LNCM][Navigation and Maritime Trade Law] as amended, Articles 91-100, Diario Oficial de la Federación [Official Federal Gazette -- D.O.], 1o. de junio de 2006 (Mex).

32 Id., Article 91.

33 Robert Force et al, Aadmiralty and Maritime Law Practitioner's Edition Volume 2266 (2008).

34 Ley de Navegación y Comercio Marítimos[ LNCM][Navigation and Maritime Trade Law] as amended, Articles 93, Diario Oficial de la Federación [D.O.], 1o. de junio de 2006 (Mex). 
As with an English or a US maritime lien, a Mexican maritime lien is secret; it does not need to be registered. ${ }^{35}$ It also attaches to the vessel until the lien is carried into effect by a preventive embargo or seizure. ${ }^{36}$ Hence, a maritime lien is not enforceable against all the assets of the person at fault but against the ship or naval artifact. ${ }^{37}$

Arguably, a maritime lien is an independent legal feature as it will be extinguished independently of the underlying claim. The Mexican legislation is unsatisfactory and rather inconsistent about the information it provides about maritime liens, however, and some Mexican authors suggest that a maritime lien is not a "derecho real" by itself but a "derecho real de garantia" 38 or a real security right.

A "real security right" is a preferential right that allows the creditor to be paid ahead of other creditors on the sale price of the asset subject to the privilege, and sometimes also allows the creditor to seize the property regardless of the ownership of the asset. ${ }^{39}$ This right to seize the asset regardless of property depends on the nature of the privilege ${ }^{40}$ or in this case, the maritime lien. Moreover, in the current Latin American systems "real security rights" only indicate priority and not the right of prosecution regardless of the ownership. ${ }^{41}$

Arguably, a Mexican maritime lien should not include the right of prosecution. Also, the holder of a maritime lien cannot start proceedings against the ship unless his claim is based on a real right or "derecho real". ${ }^{42}$ Nevertheless, the above mentioned seems to be an unsettled area for Mexican law as it is strictly linked to the ship arrest law, a measure that was incorporated into

\footnotetext{
35 Id., Article 97.
}

36 Hereafter embargo is the synonym for the arrest of a ship for purposes of Mexican legislation.

37 Abraham A. Servín, Should Mexico Adopt the 1952 International Convention for the Unification of Certain Rules in Relation to the Arrest of Sea-Going Ships or The 1999 International Convention on Arrest of Ships? (Sep, 09, 2015) (unpublished LLM dissertation, University of Southampton).

38 Jose Eusebio Salgado y Salgado, Manual de Derecho Marítimo Tomo I 545 (Editorial Academica Española 2012); Raúl Cervantes Ahumada, Derecho Marítimo 877 (Editorial Herrero, S. A. 1984); David EnríQuez Rosas, El BuQue: una Introducción al Estudio del Estatus Jurídico de las Embarcaciones 412 ( Universidad Nacional Autónoma de México, 1998).

39 Carlosa de Gores et al., El Nuevo Derecho de las Garantías Reales 38 (2008).

40 Id.

41 Id., at 40.

42 See Abraham A. Servín, Should Mexico Adopt the 1952 International Convention for the Unification of Certain Rules in Relation to the Arrest of Sea-Going Ships or The 1999 International Convention on Arrest of Ships? (Sep, 09, 2015) (unpublished LL.M. dissertation, University of Southampton). 
the Mexican maritime legislation in 2006, being the ship arrest an obscure feature for Mexican law.

Finally, the list of maritime liens that are recognized by Mexican law are stated in Article 91 as follows:

I. Claims for wages and other dues to the crew members under their employment on the vessel including repatriation costs and social security charges;

II. Claims arising from compensation due to death or injury occurring whether ashore or at sea, in direct relation to the use of the vessel;

III. Claims for salvage reward for the salvage of the vessel;

IV. Credits to the vessel, derived from the use of port infrastructure, maritime signals, waterways and pilotage;

V. Claims arising from the compensation by a non contractual fault, due to loss or material damage caused by the operation of the vessel, other than loss or damage caused to the cargo, containers, and effects of passengers carried on board the same $[\ldots]^{43}$

It is safe to say that the list of recognized maritime liens within one juridical system depends on public policy, history, and economic development especially in the area of trade. A country that has a lot of shipowners may protect ships from arrest based on a maritime lien, while a country with much stronger port developments may advantage suppliers with a maritime lien on supplies. It is natural, therefore, that very different positions about how to apply and recognize such a right exist around the world. Nevertheless, a natural sense of justice and developments in international litigation require countries to recognize this right, provided that it was validly conferred.

\section{The Recognition of Foreign Maritime Liens}

As noted before, there is no uniformity around the world with regard to the development and application of the law of maritime liens. It is natural, therefore, that conflict of laws may arise and the way courts around the world solve these problems differ depending on their conflict of laws rules. English law, for instance, restricts what claims can be considered maritime liens. The US and other civil law jurisdictions, on the other hand, have a much longer list of claims that are considered maritime liens. Therefore, having a maritime lien recognized by a foreign court could mean the difference between having

43 Ley de Navegación y Comercio Marítimos [L.N.C.M] Navigation and Maritime Trade Law] as amended, Articles 91, Diario Oficial de la Federación [D.O.], 1o. de junio de 2006 (Mex). 
Esta revista forma parte del acervo de la Biblioteca Jurídica Virtual del Instituto de Investigaciones Jurídicas de la UNAM www.juridicas.unam.mx

a right in security over the ship that travels with the property ${ }^{44}$ and being secured by a regular maritime claim or statutory right in rem. ${ }^{45}$

This conflict of laws problem gives rise to a very complicated set of questions. A claim may arise by means of a contract or a tort or any other cause of action, and the court needs to decide which law governs the claimant's cause of action. The court may need to take into consideration that a maritime lien forming security for this obligation arises not only by this cause of action but also by operation of law. ${ }^{46}$

The questions may not stop there: Should the courts of the forum arresti recognize the foreign law regarding maritime liens when that law is dissimilar to the domestic law that regulates maritime liens? and; should the courts of the forum arresti apply its national law or the foreign law to the ranking of the foreign maritime lien? ${ }^{47}$ These questions are linked to the characterization of maritime liens, and the courts will look at their conflict of laws rules to find a solution. $^{48}$

\section{Other Jurisdictilons and the Recognition of Foreign Maritime Liens}

The infamous decision on the The Halcyon Isle, ${ }^{49}$ represents the leading authority on maritime liens in English law. This majority decision of the Privy Council establishes that the lex for governs the recognition and ranking of foreign maritime liens.

The majority's position, as explained by Lord Diplock, is that a maritime lien in English law involves rights that are procedural or remedial only. ${ }^{50}$ The minority, represented by Lord Salmon, would have preferred that a maritime lien validly conferred by the lex loci be entitled to recognition. ${ }^{51}$ In other

44 Veronica Ruíz Abou-Nigm, The Arrest of Ships in Private International Law 118,119 (Oxford International Press) (2011).

45 In case of English law.

46 Griffith Price, The Law of Maritime Liens 206 (Sweet and Maxwell Limited 1940), and

Veronica Ruíz Abou-Nigm supra note 34 at 127.

47 William Tetley, International Conflict of Laws, Common, Civil, aNd Maritime 542-543 (International Shipping Publications BLAIS 1995);

William Tetley, Maritime Lien in the Conflict of Laws in Law and Justice in a Multistate

World: Essays in Honour of Arhtur T Von Mehren 439-457 (Nafzinfer \& Symeonides ed.,2002); and Ruíz AbOu-Nigm supra note 34 at 125.

48 Ruíz Abou-Nigm supra note 34 at 124.

49 Bankers Trust International Limited v Todd Shipyards Corporation (The Halcyon Isle)[1980] 2 Lloyd's Rep. 325.

$50 \quad I d$. at 331.

51 Id. at 339 . 
words, the minority recognized that a maritime lien should be classified as substantive and not procedural. ${ }^{52}$

There is a policy reason for this decision. Apparently, Lord Diplock was concerned about the extensive list of actions that can lead to the award of maritime liens in some jurisdictions. Whereas English law authorizes maritime liens from a restricted set of circumstances, the US and France, for instance, have a wider range of claims that can give rise to maritime liens, including one for necessaries men, which is a very broad claim. ${ }^{53}$ From that perspective, the recognition of foreign maritime liens may constitute an injustice to a purchaser or a mortgagee. ${ }^{54}$

The main objective of the lex fori approach then, is to work as an "escape device", ${ }^{55}$ rendering less inconvenient the application of foreign elements, which may be unfamiliar to the court. ${ }^{56}$ Lord Diplock identified two possible answers: to use the lex fori approach or to apply a complicated kind of partial renvoi. The first option, he noted, had the merit of simplicity and was preferable in principle. ${ }^{57}$

This approach favors "forum shopping" as it benefits those claimants who are in a position to take advantage of this opportunity, like mortgagees ${ }^{58}$ or even further as in OceanConnect UK Ltd v Angara Maritime Ltd ${ }^{59}$ a court of appeal case involving US law maritime lien for supplies. In 2009, OCEANCONNECT arrested the vessel in Amsterdam in respect of its claim, and the parties agreed on the release of the vessel upon security. The agreement stated that the monies due would be paid following judgment in a competent court of law and provide an English exclusive jurisdiction clause and an English applicable law clause. Following the re-arrest of the vessel in the US in 2009, the appellant, sought to set aside an anti-suit injunction.

In this case the judge identified the problems that would arise if the order were upheld, given that under English law the recognition of a foreign maritime lien is lex fori and that English law does not grant a maritime lien for

52 For a summary of the position of the academics refer to: Steve Rares, Maritime Liens, Renvoi and Conflicts of Law: The Far from Halcyon Isle, LMCLQ 183, 183-202 especially 191-193 (2014).

53 Bankers Trust International Limited v Todd Shipyards Corporation (The Halcyon Isle)[1980] 2 Lloyd's Rep. 325 at 331,332.

54 C.A. Ying, Priorities and the Foreign Maritime Lien 8 Adel.L.Rev 95, 98 (1982-1983).

55 RUÍZ ABOU-NIGM supra note 34 at 130, 133.

56 T.A.G. Beazley, Maritime Lien in the Conflict of Law 22 Malaya L Rev 115 (1978).

57 Bankers Trust International Limited v Todd Shipyards Corporation (The Halcyon Isle)[1980] 2 Lloyd's Rep. 325 at 327.

58 William Tetley, Maritime Lien in the Conflict of Laws in LLaw AND Justice IN A Multistate World: Essays in Honour of Arhtur T Von Mehren 439-457 (Nafzinfer \&Symeonides ed.,2002) and Ruíz Abou-Nigm supra note 34 at 131.

59 OceanConnect UK Ltd v Angara Maritime Ltd (Civil Division) [2010] EWCA Civ 1050 . 
Esta revista forma parte del acervo de la Biblioteca Jurídica Virtual del Instituto de Investigaciones Jurídicas de la UNAM www.juridicas.unam.mx

necessaries. OCEANCONNECT would not be entitled to a maritime lien and therefore they would not be able to proceed in rem. ${ }^{60}$

According to William Tetley, the Rome Convention $1980^{61}$ may have changed the law regarding the recognition of foreign maritime liens. The author bases his theory on articles $1(2)(\mathrm{h})$ and 14. These articles lessen the importance of procedure ${ }^{62}$ and state that the governing law would apply to the extent that "applicable law" should raise presumptions of law, in this case the lien. Now, this provision has been reproduced in a similar fashion in the Rome I Regulation on the law applicable to contractual obligations ${ }^{63}$ in its articles 1(3) and 18, and in the Rome II Regulation on the law applicable to non-contractual obligations ${ }^{64}$ in its articles 1(3), 21 and 22. Although, by the decision in OceanConnect UK Ltd v Angara Maritime Ltd it appears that The Halcyon Isle ${ }^{65}$ is still the authority regarding recognition of foreign maritime liens, it can be argued that by virtue of the Rome I and Rome II regulations, a maritime lien would be recognized even when the maritime lien would rank according to English law. ${ }^{66}$

The United States regards the right to arrest a vessel through an action in rem as synonymous with maritime liens ${ }^{67}$ therefore, under US Law, a maritime lien constitutes a substantive right. ${ }^{68}$ A US court would use a choice-oflaw criterion in order to determine the governing law that should confer a maritime lien on a claimant.$^{69}$ If the court does not decide to dismiss the case under the doctrine of forum non convenience, it will allow the claimant to proceed in rem, but the ranking will always be governed by US Law. ${ }^{70}$

Given the above outline, Martin Davis notes that under US Law, it is of paramount importance to address three choice-of-law topics: the law governing the underlying claim; the law that gives access to a maritime lien in the specific case and; the law governing the ranking of the lien. ${ }^{71}$

\footnotetext{
60 Id. at 39.

61 Rome Convention on the law applicable to contractual obligations 1980; the consolidated text at [1972] OJ C028/34.

62 Tetley supra 48.

63 Regulation (EG) 593/2008 [2008] OJ L177/6.

64 Regulation (EC) 864/2007 [2007] OJ L199/40.

65 Bankers Trust International Limited v Todd Shipyards Corporation (The Halcyon Isle)[1980] 2 Lloyd's Rep. 325.

66 TETLEY supra 48.

67 Charles A. Donovan, Picking the Shipowner's Poison-Choice-of-Law Classes and Maritime Liens 14 U S F Mar LJ 185, 195 (2001-2002).

68 Id., at 195.

69 FORCE supra 23 at 185.

70 Tetley supra 48.

71 Martin Davis, Choice of Law and U.S. Maritime Liens 83 Tul L Rev 1435, 1436 (20082009).
} 
The US conflict of laws rules would find the proper law because it is expressly declared in the relevant contract or contracts or because the connecting factors indicate that the "proper law" is the law of other jurisdiction. ${ }^{72}$ To illustrate this, in Exxon Corp. $v$ Central Gulf Lines, ${ }^{73}$ a case that relates to a bunkering performed in Saudi Arabia, the court found that US law was the proper law:

Plaintiff Exxon contends that American law should govern whether maritime liens exist in this case. Defendant does not oppose this contention. I agree that this case should be decided according to American law. The United States has a significant interest in this case. The shipowner, the charterer, the ship, and the plaintiff were all American. On the other hand, Saudi Arabia has no interest in having its law apply in this case. The only foreign participant in this transaction, Arabian Marine, was not injured. See Lauritzen v. Larsen, 345 U.S. 571, 582-90, 73 S. Ct. 921, 928-32, 97 L. Ed. 1254 (1953); Rainbow Line, Inc. v. M/V Tequila, 480 F.2d 1024, 1026-27 (2d Cir. 1973).

Also, the proper law approach is exemplified in Ocean Ship Supply Ltd. v. $M / V$ Leah $^{74}$ a Fourth Circuit decision in which a Greek ship obtained necessaries in Quebec, Canada. The ship was subsequently sold and registered in Honduras. Afterward, the ship was arrested in Charleston, United States. The court decided that the applicable law was Canadian law. Therefore, the purchase of the vessel defeated the statutory right in rem that was conferred by Canadian law for claims of necessaries. ${ }^{75}$ In the case of Oil Shipping (bunkering) B. V. v Sonmez Denizcilik ve Ticaret A.S. ${ }^{76}$ it was not disputed that the plaintiff was entitled to a maritime lien for necessaries simply because Turkish law provides for such a lien.

To summarize the US position as expressed by Martin Davis, under US law there is an axiomatic connection between conferral of a maritime lien under the lex causae and the recognition of a maritime lien in the US. ${ }^{77}$

The position at Canadian law is the one established in the Ioannis Daskalelis. ${ }^{78}$ in this Supreme Court case Mr Justice Ritchie stated that if a maritime lien exists, it cannot be shaken off by changing location of the res. ${ }^{79}$ In other

72 Tetley supra 48; William Tetley, supra 37 at 552-565; Charles A. Donovan Picking the Shipowner's Poison - Choice-of-Law Classes and Maritime Liens 14 U S F Mar LJ 185, 185201 (2001-2002).

73 Exxon Corp v Central Gulf Lines, Inc. 707 F. Supp. 155 (S.D.N.Y. 1989).

74 Ocean Ship Supply Ltd. VM/V Leah729 F.2d 971, 194 AMC 2089 (4 Cir. 1984).

75 TetLey supra 37 at 552.

76 Oil Shipping (Bunkering) B.V. v Sonmez Denzcilik ve Ticaret A.S. 10 F.3d 1015 (3d Cir. 1993).

77 Davis supra 61 at 1438.

78 Todd Shipyards Corporation v The Ship Ioannis Daskalelis[1974]1 Lloyd's Rep 174.

79 Id. at 176. 
Esta revista forma parte del acervo de la Biblioteca Jurídica Virtual del Instituto de Investigaciones Jurídicas de la UNAM www.juridicas.unam.mx

words, if a maritime lien is validly created by a foreign law, this lien can be equally enforced in Canada by an action in rem. ${ }^{80}$ Consequently, according to Canadian law, a maritime lien is characterized as a substantive right and the validity and nature of this right or lien depends upon the proper law of the situation that gives rise to the claim. ${ }^{81}$ The ranking is also procedural or remedial, therefore determined by the lex fori. ${ }^{82}$

In the Lanner ${ }^{83}$ it was held that whenever a Canadian court is asked to apply a substantive law of a foreign jurisdiction, the Canadian conflict of laws rules must be applied in order to determine what choice of law to employ. ${ }^{84}$ In addition, the judges acknowledged that a maritime lien arises by operation of law, and consequently, they are extra-contractual rights, so there might be cases in which it is necessary to look for the connecting factors rather than the choice of law clause in the contract. ${ }^{85}$

In Reiter Petroleum Inc v The Ship "Sam Hawk", the Federal Court of Australia faced a complex situation in relation to the existence and recognition of a US maritime lien. The main question was whether the Halcyon Isle decision still governed the law of Australia. The court considered, in particular, the nature of maritime liens and the test of what should be regarded as procedural or substantive matters, as proposed in Fohn Pfeiffer Pty Ltd v Rogerson. ${ }^{87}$

While measuring the pivotal issue of the case Judge McKerracher said:

[...] matters that affect the existence, extent or enforceability of the rights or duties of the parties to an action are matters that, on their face, appear to be concerned with issues of substance, not with issues of procedure. Or to adopt the formulation put forward by Mason CF in McKain (1991) 174 CLR 1 at 26-27, rules which are directed to governing or regulating the mode or conduct of court proceedings «are procedural and all other provisions or rules are to be classified as substantive.» ${ }^{88}$ (Emphasis added).

The court recognized that in light of this new test, a maritime lien should be regarded as a matter of substance rather than procedure. After re-evaluating the authorities, McKerracher stated that even viewing the topic his-

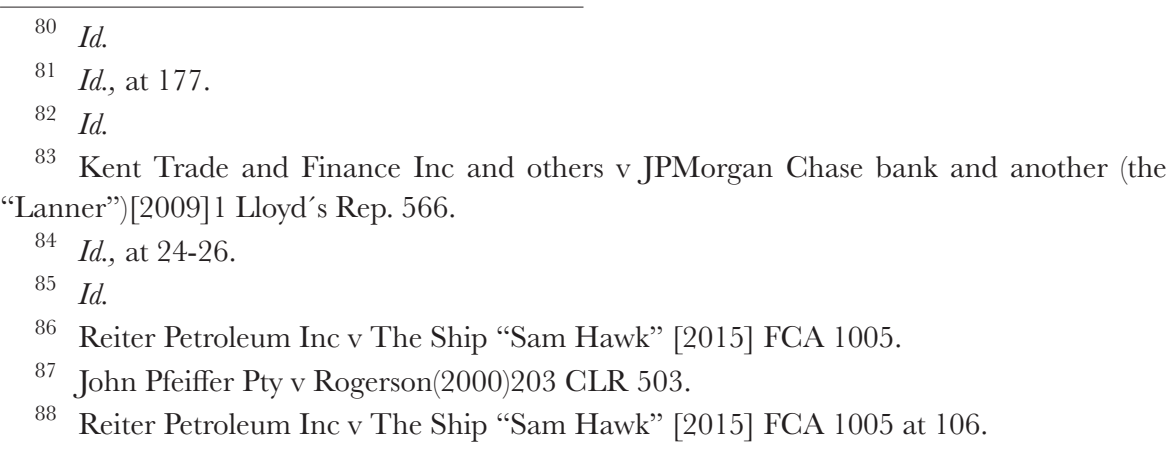


Esta revista forma parte del acervo de la Biblioteca Jurídica Virtual del Instituto de Investigaciones Jurídicas de la UNAM www.juridicas.unam.mx

torically, it seemed clear that a maritime lien is more than a procedural or remedial right. ${ }^{89}$

Furthermore, the court supported the minority ratio decidendi in the Halcyon Isle in the Fohn Pfeiffer case. ${ }^{90}$ Finally, the court recognized that an Australian court should recognize and enforce a maritime lien arising under foreign law.

\title{
2. An Approach to the Recognition of Foreign Maritime
}

Liens Under Mexican Law

Mexican courts have not yet had to wrestle with a maritime lien created by a foreign law at odds with local legislation.

The Federal Civil Code, ${ }^{91}$ however, has conflict of laws rules for civil matters that may provide Mexican courts with some direction.

Article 12 reads as follows:

\begin{abstract}
Mexican law governs all persons who are within the republic, as well as the acts and events occurring within its territory or jurisdiction and those who submit to Mexican law, except when these provide for the application of a foreign law and also, those provisions set forth in treaties and conventions to which Mexico is a party. ${ }^{92}$ (Emphasis added).
\end{abstract}

Although seemingly territorialist, Article 12 appears open to the application of foreign law when Mexican legislation provides that option.

On the one hand, under the situation that is analyzed in this paper, it would be inconsistent to hold that Mexican law is applied because the main cause of action occurred within the Mexican jurisdiction. To illustrate this point, a maritime lien arises under a different law from Mexican law and then attaches to a vessel and travels with the vessel until the plaintiff seeks to enforce his right by arresting the ship. On the other hand, it may be harsh to say that Mexican law applies just because the plaintiff is within the jurisdiction. Therefore, it is necessary to look at articles 13,14 and 15 where the conflict of laws rules that provide for the application of foreign law are codified.

Article 13 sets out the connecting factors that may determine the applicable law:

\footnotetext{
89 Id., at 115.

90 Id., at 119.

91 Código Civil Federal [Federal Civil Code-C.C.F.] [Navigation and Maritime Trade Law] as amended, Articles 12-15, Diario Oficial de la Federación [D.O.], 1o. de junio de 2006 (Mex).

92 Id., Article 12.
} 
Determination of applicable law shall be done according to the following rules:

i. legal situations validly created, in the entities of the Republic or in a foreign state under its law, shall be recognized.

ii. the status and capacity of natural persons is governed by the law of the place of residence.

iii. the constitution, regime and extinction of real rights over non movable assets, and movable assets, and leases and temporary use of such property shall be governed by the law of the place of its location, although its owners are foreign.

iv. the form of legal acts is governed by the law of the place where it is held. However, they may be subject to the forms prescribed in this code when the act is to take effect in the Republic or in the Distrito Federal or in the case of a federal matter; and

v. except as provided in the previous sections, the legal effects of acts and contracts are governed by the law of the place where they are to be executed, unless the parties have validly designated the applicability of another law. ${ }^{93}$ (Emphasis added).

Furthermore, three possible connecting factors can be identified in the case of the recognition of foreign maritime liens. Article 13 (i) states that in order to recognize any right, it must be validly conferred under the foreign law. It follows, then, that it is necessary to look at the rules on conflict of laws in order to determine which statute confers the disputed right.

First, Article 13 (iii) states that in case of movable assets, the connecting factor is the lex rei sitae or the place where the asset is located. Therefore, two assumptions may be inferred.

The fact that the vessel is arrested within Mexican jurisdiction fixes the law of the forum as the applicable law. Interestingly, the lex rei sitae as a connecting factor has been used as a device to use the lex fori approach in other jurisdictions. $^{94}$

Conversely, it can be argued that the connecting factor could be the domicile of the owner. ${ }^{95}$ However, a more suitable factor to this specific case could be the nationality of the vessel or the law of the ship's flag. But this approach can cause some problems. First, as acknowledged by Professor William Tetley, nowadays "there is no value to the law of the flag in a world of flags of convenience." "F6 Furthermore, by taking this approach, the vessel would be subjected only to its own law, rendering injustice to the claimant, such as in the case of, a US tanker supplier trying to enforce his lien without knowing that the nationality of the vessel is Nigerian and that Nigerian law does not provide for a maritime lien on supplies.

\footnotetext{
93 Id., Article 13.

94 Ruíz Abou-Nigm supra note 34 at 130.

95 Leonel Pereznieto Castro, Derecho Internacional Privado parte general 348 (Oxford University Press 2015).

96 TetLey supra 37 at 582.
} 
Second, article 13 (iv) states that the connecting factor would be the $l^{-}$ cus regis actum. This approach seems the most suitable as it would require an analysis of the underlying claim in order to determine the place where it was held. For instance, first, the court would characterize the matter, for example as a tortuous matter, and then the court would determine the place where the tort was committed. Additionally, when the place of performance of the obligation is Mexico, Mexican law would be the applicable law.

Third, article 13 (v) works as a residual category as it states that without prejudice to the other subsections of this article, the legal effects of the acts and contracts will be governed by the law of the place of execution. ${ }^{97}$ Moreover, this article identifies in some way the principle of freedom of contract by giving recognition to a valid governing law clause, clauses that are very common in the maritime business.

Consequently, the "applicable law" issue does not have a clear-cut answer as the Mexican courts can take either a very protective approach or, to be fairer to the parties, a more complicated one.

Furthermore, Mexican jurisprudence provides another approach for a Mexican judge to characterize ${ }^{98}$ this kind of situation. Characterization under Mexican law would help the judge to find the applicable law and guide him in its application. ${ }^{99}$ This characterization would occur because of the need to define the assumptions of the case and to find the previously mentioned connecting factors. ${ }^{100}$

The importance and use of this characterization is explained by Maria Soledad Hernandez Ruiz de Mosqueda in the following excerpt:

[...] In its legal sense it (the characterization) is used to determine the legal nature of a relationship in order to classify it in a category regulated by law; or, the reasoning by which it is decided that a number of facts are referred to a certain rule of law. [...] the study of characterization is particularly relevant in private international law because this area of the law is of particular relevance: when several legal systems, which provide different characteristics and definitions relate to a certain matter, it is necessary to know which of these systems should prevail, for instance, which of them will determine the characterization. This choice will determine the applicable law to

97 Abraham A. Servín, Should Mexico Adopt the 1952 International Convention for the Unification of Certain Rules in Relation to the Arrest of Sea-Going Ships or The 1999 International Convention on Arrest of Ships? (Sep, 09, 2015) (unpublished LL.M. dissertation, University of Southampton).

98 This characterization process usually happens after the Mexican judge looks at his conflict of laws rules.

99 Quinto Tribunal Colegiado en materia civil del primer circuito. Amparo directo 740/2010. I.5o.C.28 C (10a.). (María Soledad Hernandez Ruiz de Mosqueda).

100 Id. 
this conflict of lawe, because this choice implies the conflict of lawes rules that will regulate this matter [...]. ${ }^{101}$ (Emphasis added).

There are three ways to effect this characterization under Mexican law: the lex for method, the lege causae method, and the comparative method. ${ }^{102} \mathrm{It}$, however, limits itself to describing the three methods and does not detail the complications that can arise by the use of any of these options, thereby leaving the final choice up to the presiding judge.

[...] 1. Qualification by the lex fori. This method involves the application of the domestic legal system categories by the judge to determine the characterization, and is based on several arguments: a) The rules of private international law are part of a legal system that, in order to maintain consistency, also has a number of concepts and definitions that the legislator uses in order to create its rules. If the problem of characterization refers to the interpretation of the law (referring to the established legal categories) it is indisputable that it must correspond to its own system

b) The characterization has a previous character in the conflict of lawes. Its function is to put into operation a conflictual norm to help to determine the law that is applicable to the substance of the matter. The only rules that the judge may consider are the ones of his own system. The judge cannot use a foreign system when he does not know whether this law is applicable. Such an assumption would lead to a vicious circle.

c) The judge, as the authority on his own system, is required to use the concepts of this system that are the result of a particular legislative policy and respond to sociological, political and international factors that the legislators have taken into account and processed in a particular way. ${ }^{103}$ (Emphasis added).

As mentioned before, using this approach could be considered to be excessively protective. This approach uses the law of the state in a conflict in which a foreign element is clearly the issue, and if the nature and concept of the local law is different, as in the case of maritime liens in Mexican and US laws, then a judge using the domestic definition may interpret the norm in a restrictive way, and this may be dangerous to the right to justice that a plaintiff has.

[...] 2. Characterization lege causae. Consists in the definition of legal concepts in compliance with the foreign law that may be applicable to the matter. It is based on the argument that foreign law is a unit that cannot be arbitrarily broken, if its application is subject to foreign standards. If it is based on categories that are not their own, the unit breaks down and the result will be the implementation of a reformed law. This method reveals the complexity of the charac- 
terization, emphasizing the real presence of foreign law in the relationship and pointing to the dangers of absolute application of the lex fori. ${ }^{104}$

The absolute application of this approach may, as inferred by Lord Diplock in the Halcyon Isle, ${ }^{105}$ extend and reform the nature of features that also may exist in the judge's legal system. In other words, a judge using this approach may end up recognizing the foreign law in its full extent, but at the same time he will be modifying and affecting the established institutions of his own legal system.

[...] 3. Comparative Method. This comes from the need to create truly appropriate conflict of laws rules to deal with international problems, whose concepts give answer to the possibility of applying different rules to the ones provided in the judge's system without changing the nature of that rule,_respecting the unknown institutions $[\ldots] .{ }^{106}$

This appears to agree with the principle that the characterization shall be done independently of the problems that may arise from the application of the judge's legal system. In other words through a comparative study of the institution, this approach provides solutions of and amendments to how to characterize the matter. However, it seems that the application of this method requires the judge to research the matter thoroughly or possess expert level knowledge of it.

After identifying the applicable law, it is then necessary to assess the issue of the application of that foreign law. These rules are set out in Article 14:

In the application of foreign law, the following shall be followed:

i. It will be applied as the corresponding foreign judge would have applied it, for which the judge may gather the necessary information about the text, validity and scope of that law;

ii. Foreign substantive law shall apply, except when due to the special circumstances of the case, it is necessary, in an exceptional case, to look at their conflict of laws rules that make a substantive right, either from Mexican law or from the law of a third State, applicable;

iii. It will not be an impediment to the application of foreign law that Mexican law does not provide institutions or procedures essential to the applicable foreign institution, if there are institutions or similar procedures;

iv. Previous, preliminary or incidental issues that may arise during the trial of the main issue, should not necessarily be resolved in accordance with the law governing the latter; and

\footnotetext{
104 Id.

105 Bankers Trust International Limited v Todd Shipyards Corporation (The Halcyon Isle)[1980] 2 Lloyd's Rep. 325.

106 Quinto Tribunal Colegiado en materia civil del primer circuito. Amparo directo 740/2010. I.5o.C.28 C (10a.). (María Soledad Hernandez Ruiz de Mosqueda).
} 
v. When different aspects of the same legal relationship are governed by various laws, they will be applied harmoniously in order to attain the purposes pursued by each of such rights. The difficulties caused by the simultaneous application of such rights shall be resolved taking into account the requirements of equity in the case. The provisions of this Article shall be observed when the right of another entity of the federation becomes applicable. ${ }^{107}$ (Emphasis added).

Article 14 provides us with a bit of a conundrum. On the one hand the first part of subsection ii declares that the local courts must apply the foreign law in cases of substantive rights, which shows that the characterization of a maritime lien will be the main issue for their recognition as discussed before. However, it appears that the international maritime reality is that the majority of the most important maritime nations that have dealt with this problem recognize a maritime lien as a substantive right. Furthermore, a Mexican maritime lien seems to share most of the features of a maritime lien that arises under other jurisdictions.

On the other hand, the second part of subsection (ii) allows for the possibility of applying a renvoi if this points toward Mexican substantive law or another law that may be determinative, whenever the extraordinary features of the case require it. Moreover, there is no guidance on what the words "special circumstances" or "exceptional" could possibly mean. From this perspective, it seems that this second part is an escape clause to use substantive Mexican law or avoid a complicated renvoi.

Article 14 (i) says the Mexican judge has a right to gather the necessary information about the foreign law in order to apply that foreign law as the judge of that jurisdiction would have done it. Therefore, it is convincing to say that the judge may accomplish this by his own means or by asking the parties, such as experts, to provide evidence of this law. ${ }^{108}$ Moreover, the jurisprudence makes it clear that there is a burden of proof on the claimant on the existence, text and scope of the foreign law. ${ }^{109}$ This may be explained by the fact that the judges are masters of the law of their own legal system, and even though they have the obligation to gather information, the pace, and volume of work of the Mexican courts make this task very difficult. ${ }^{110}$

107 Código Civil Federal [C.C.F.] [Navigation and Maritime Trade Law] as amended, Article 14 Diario Oficial de la Federación [D.O.], lo. de junio de 2006 (Mex).

108 Loenel Pereznieto Gastro, Derecho Internacional Privado parte general 351 (Oxford University Press 2015).

109 Tercer Tribunal Colegiado en materia civil del primer circuito. Amparo directo 10623/2001. I.3o.C.302 G. (Armando Cortez Galvan).

Quinto Tribunal Colegiado en materia civil del primer circuito. Amparo directo 740/2010. 1.5o.C.33 C (10a.).(María Soledad Hernández Ruiz de Mosqueda).

110 It would be valid to say that this burden of proof and obligation to gather information 
Before this analysis of the Mexican legislation on recognition of foreign law, we examined the nature, the definition and the differences between maritime liens in English law, American law and Mexican law and between civil law and common law in general. If the lex for is used to characterize the situation it is highly probable that only the maritime liens provided for by Mexican legislation will be recognized.

Article 14 (iii) does not see it as an impediment to the application of foreign law if Mexican law does not cater precisely for those procedures set out in the foreign law, if there are Mexican institutions and procedures with similar proceedings. The question arises, therefore, to what extent will Mexican courts recognize a foreign maritime lien? Is the Mexican judge to recognize the foreign maritime lien simply as a privilege or are they going to accept the right to proceed in rem and therefore the right to prosecute the vessel regardless of ownership?

If the first assumption is right, what is the value of the recognition of the foreign maritime lien? If it may be held that the applicable procedures or institutions are the Mexican ones, then it may be held that the ranking is up to the lex fori. ${ }^{111}$ Conversely, if the second assumption is right, is the Mexican judge to grant the right to proceed as a real right in order to satisfy the Mexican institutions of arrest of ships and maritime liens?

Finally, Article 15 provides an exception to the application of foreign law.

I. When principles of Mexican law have fraudulently been evaded, the judge must determine the fraudulent intention of such evasion

II. Where the provisions of foreign law or the outcome of its application are contrary to fundamental principles or institutions of Mexican public order. ${ }^{112}$

It is left up to the judge to determine what constitutes "fraudulent intention", "fraud to the law" and "public order".

\section{Conclusions}

Despite there being no uniformity in the laws of maritime liens, it is a common feature in many legal systems that a maritime lien creates an interest in the vessel, one that shall be enforced through the arrest of the res. The

exist in the very early stages of the claim, for example, in order to characterize the lien according to the applicable law.

111 There is no other indicator of the nature of the ranking. Abraham A. Servín, Should Mexico Adopt The 1952 International Convention For The Unification Of Certain Rules In Relation To The Arrest Of Sea-Going Ships or The 1999 International Convention On Arrest Of Ships? (Sep, 09, 2015) (unpublished LLM dissertation, University of Southampton).

112 Código Civil Federal [C.C.F.] [Navigation and Maritime Trade Law] as amended, Article 15 Diario Oficial de la Federación [D.O.], 1 de junio de 2006 (Mex). 
dynamism and complexity of the maritime business pushes all the involved parties to seek advantages. The availability of this feature plays a very important role in current maritime business. Consequently, this situation creates forum shopping. On the one hand, companies that provide supplies to vessels look for the protection of a more favorable jurisdiction, as in the example of the "Sam Hawk", which, though Reiter Petroleum had little or no connection at all to the United States, they established in a contract that the creation of maritime liens should be governed by US law. On the other hand, the nature of maritime business makes it necessary for its workforce to seek out jurisdictions that recognizes the right to arrest a ship by reason of maritime liens.

Interestingly, the position in Mexican law is unclear. Despite the fact that the list of maritime liens under Mexican law is fairly extensive, national legislation leaves many obscure areas. The domestic law provides both tools to recognize such an important maritime feature to its full extent, and the means to adopt a more territorial approach and not treat the feature to its full extent. If a Mexican court were to face this situation, the commercial and maritime experience of the presiding judge would play an important role in the decision, as this topic requires a deep knowledge of maritime law, contract law, insurance law etc.; a good understanding of foreign law and; an awareness of all new developments in international litigation. Moreover, as stated by Lord Salmon, ${ }^{113}$ the judge must take into account "the balance of authorities, the comity of nations, private international law and natural justice." 114

There is an intrinsic relationship between maritime liens and the arrest of ships. Hence, there is a need for the Mexican legislator to re-analyze the nature of these two institutions. In this regard, the law of the arrest of ships has been recently added to our legal system, when in other maritime nations this has been a pivotal part of the discussion about the nature of maritime liens. The legislator should analyze the positions of other jurisdictions upon the nature of these two maritime features and the problems that may arise in their treatment in order to harmonize our legislation with the international reality and bring justice to a plaintiff seeking to enforce his right to a maritime lien that was conferred elsewhere.

The legislator and the academics should pay special attention to the true nature of maritime liens in the sense that a clear position must be established on the issue of whether maritime liens should be treated as a "derecho real" by itself or as a "derecho real de garantía", and what the scope and implications are of treating this juridical feature as either. If it is to be treated as a "derecho real," the legislator and the academics should define the spectrum of such a feature. ${ }^{115}$ If it is to be treated as a "derecho

113 Who represents the minority on The Halcyon Isle.

114 Bankers Trust International Limited v Todd Shipyards Corporation (The Halcyon Isle)[1980] 2 Lloyd's Rep. 325 at 337.

115 Because as a matter of history it is understood that a maritime lien includes the right to 
real de garantía" a study on the handling of maritime liens around the world should be done, paying special attention to the right of prosecution regardless of possession, as in theory a "derecho real de garantía" may include this right ${ }^{116}$ To be studied as well is whether a maritime lien is to be treated as a matter of substance or a matter of procedure.

Mexican jurisprudence and law are wide open to the interpretation and criteria of the judge regarding situations in which the judge is asked to recognize and apply foreign law. Mexican conflict of laws rules have a mixed approach: they provide for both a territorial and a more international approach, and the law offers the same options without setting out comprehensively when to apply either approach. There is a powerful need for comprehensive conflict of laws rules and other legal guidelines on how and when to apply foreign law in situations such as those examined in this paper.

In other words, lawmakers need to understand that the developments of the trade and the swift pace of international transactions require forums in which those who interpret the law are capable of applying an international feature such as a maritime lien and of enforcing it through the arrest of the ship.

be a preferential creditor, this debate should involve the law on real rights and the implications of defining a maritime lien as such.

116 As mentioned before it seems that in most of the cases in Latin America a "derecho real de garantía" is treated as a mere cause of preference. 